\title{
A study of syndromic and etiological approach for the diagnosis of reproductive tract infections
}

\author{
Surbhi Saharan* \\ Department of Obstetrics and Gynecology, Mahatma Gandhi Medical College and Hospital, Jaipur, Rajasthan, India \\ Received: 17 April 2018 \\ Accepted: 23 April 2018 \\ *Correspondence: \\ Dr. Surbhi Saharan, \\ E-mail: spiffingsurbhi@gmail.com \\ Copyright: () the author(s), publisher and licensee Medip Academy. This is an open-access article distributed under \\ the terms of the Creative Commons Attribution Non-Commercial License, which permits unrestricted non-commercial \\ use, distribution, and reproduction in any medium, provided the original work is properly cited.
}

\begin{abstract}
Background: Reproductive tract infections (RTIs) are one of the most common and major health problem around the world and they are much more widespread in developing countries than in developed countries due to Inadequate health services.

Methods: Detailed history including, menstrual, obstetric and sexual history of the patients were taken and general, physical and local examination was done and clinical symptoms and sign were noted using a structured screening proforma.

Results: In our study syndromic approach has a moderate diagnostic accuracy in detecting vaginal discharge syndrome and pain abdomen syndrome. Syndromic diagnosis is low cost effective, more acceptable and easily available at primary and secondary health centre. It should be continued as first line management.

Conclusions: In present study the vaginal discharge syndrome has sensitivity of $64.71 \%$ and specificity of $57.14 \%$, PPV $61.11 \%$, NPV $60.87 \%$ and accuracy is $61 \%$. If treatment is given only on the basis of syndromic approach for vaginal discharge syndrome it results in over-treatment in $42.86 \%$ (false positive) and under diagnosis in $35.29 \%$ (false negative). This approach was found less effective. For lower pain abdomen syndrome the sensitivity is $21.74 \%$ and specificity is $84.62 \%$, PPV $38.46 \%$, NPV $70.97 \%$ and accuracy is $65.33 \%$. If treatment is given only on the basis of syndromic approach for lower pain abdomen syndrome results in over -treatment in $15.38 \%$ (false positive) and under diagnosed 78.26\%.(false negative). This approach was found less effective.
\end{abstract}

Keywords: Reproductive tract infections, Syndromic and etiological approach, Vaginal discharge syndrome

\section{INTRODUCTION}

Reproductive tract infections (RTIs) are one of the most common and major health problem around the world and they are much more widespread in developing countries than in developed countries due to Inadequate health services. ${ }^{[1]}$ These infections cause suffering and distress for both women and men around the world but their consequences are far more devastating and widespread among women than men. ${ }^{[2,3]}$

Reproductive tract infections (RTIs) account for the second most important cause for morbidity and mortality in women of reproductive age due to the lack of medical facilities available. Untreated diseases lead to long term complications- chronic abdominal pain (PID), ectopic pregnancy, infertility and cervical cancer. ${ }^{1}$

Reproductive tract infections is a generic term which includes three types of infection:

\section{Endogenous infections}

Infections that result from endogenous overgrowth of organisms normally present in the reproductive tract (Bacterial vaginosis and vulvo-vaginal candidiasis and 
other infections). ${ }^{4,5}$

\section{Iatrogenic infections}

Infections caused by poor delivery practices, unsafe abortion, irresponsibly executed pelvic examination, and IUD insertion. ${ }^{4,5}$

\section{Sexually transmitted infections (STIs)}

Sexually transmitted infections are more dynamic than other infections prevailing in the community. ${ }^{6,7}$ In India, bacterial infections such as syphilis, chancroid and gonorrhea used to be major STIs. ${ }^{6,8}$ Viral agents such as Herpes Simplex Virus (HSV) and Human Papilloma Virus [HPV] are responsible for Genital Herpes, Genital Warts and Cervical Cancer.

Globally, Sexually Transmitted Infections constitute a major public health problem.Prevalence are higher in developing countries where STI treatment are less accessible. ${ }^{6,9}$ Sexually Transmitted Infections (STIs) are infections that are transmitted from one person to another person through sexual contact. ${ }^{6,10}$

Reproductive tract infections (RTIs) are divided into

- Upper Reproductive Tract Infections (PID) endocervix, uterus, fallopian tube, ovary, and pelvis.

- Lower Reproductive Tract Infections (vulva, vagina, and ectocervix).

\section{METHODS}

This prospective study was conducted at Department of Obstetrics and Gynecology in Mahatma Gandhi Medical College and Hospital, Sitapura, Jaipur. Study period was from December 2015 to June 2017.

\section{Method of collection}

The ethical committee of mahatma Gandhi medical college, jaipur was informed about the intended work and permission was obtained to conduct the work.

\section{Number of cases}

In present study 300 patients attending Gynae 2 OPD In MGH during DEC 2015- June 2017 of reproductive tract infections patients and willing to undergo the study were taken. These will be selected based on inclusion and exclusion criteria.

\section{Inclusion criteria}

- Women of reproductive age group (20-45 yr)

- women presenting with various symptoms and signs of RTIs (Vaginal discharge, pain in lower abdomen and genital ulcer).

\section{Exclusion criteria}

- Patient not given valid consent.

- Unmarried women.

- Women with pregnancy and any uterine pathology.

- Patient with bleeding per vagina.

- Diagnosed genital malignancy.

The angle between the ultrasound beam and direction of blood flow was maintained below 450 for umbilical artery. The umbilical artery was studied in a free loop. Umblical artery (UA) systolic diastolic ratio $>2$ SD above mean or absent or reversed end diastolic flow in umbilical artery was taken as abnormal. UA PI and UA RI were measured and value $>2 S D$ was taken as abnormal. The middle cerebral artery was visualised at the circle of Willis and was insonated soon after its origin from internal carotid artery and the angle of insonation kept close to 00 . The pulsatility index was measured and cerebroumblical PI ratio calculated. MCA-RI was considered abnormal if measurement was 2 SD below the mean. All the ultrasound evaluations were done by a single obstetrician with expertise in Doppler sonography.

\section{Detailed clinical history}

Detailed history including, menstrual, obstetric and sexual history of the patients were taken and general, physical and local examination was done and clinical symptoms and sign were noted using a structured screening proforma. Before proceeding for local examination following things were kept ready:-

One sterilized swab sticks glass test tube for culture and other test tube for other tests.

- Sterilized normal saline.

- $10 \% \mathrm{KOH}$.

- Clean and dry glass slides.

- $1 \mathrm{ml}$ of normal saline in a vial.

- Narrow range PH stripes.

- A pair of sterilized gloves.

- Pap's smear (liquid base cytology material).

- Unlubricated speculum.

- Glass marking pencil.

The patient was made to lie down in dorsal position. Then local examination was done. Inspection of vulva for edema, congestion, scratch mark or any ulcer, was carried out. Speculum examination was next done - after swabbing the perineum with boiled water (no antiseptic or lubricant was used). Condition of vagina, presence of congestion, petechial hemorrhages on vaginal wall were noted.

Condition of cervix presence of congestion or erosion of cervix, cervicitis, endocervicitis, cervical growth or ulcer were looked for. 
1st step was to take culture from posterior fornix of the vagina with sterile swab stick and send for culture and sensitivity. And then $\mathrm{PH}$ of vaginal discharge noted by PH strips dipped in vaginal discharge, change in color was noted. Discharge collected on the posterior blade of speculum was taken on the different glass slides for the preparation of different tests (wet mount, $\mathrm{KOH}$ mountwhiff test, Gram's staining) and pap's smear taken with help of ayre's spatula. The odour of the discharge was noted and also did whiff test (bacterial vaginosis), and types of color and nature of discharge also noted.

Internal examination (per vaginal) was done to find out the size, shape of uterus and rule out the tenderness and masses in the fornix and all patients underwent USG to rule out the pelvic pathology.

\section{RESULTS}

The Present study on syndromic and etiological approach for diagnosis of reproductive tract infections was conducted on 300 gynae patients of reproductive age group (20-45yrs) attending the gynecology OPD at Mahatma Gandhi Medical College and Hospital.

Table 1: Distribution of the cases according to chief complains.

\begin{tabular}{|lll|}
\hline Chief complain** & Number & Percentage \\
\hline Vaginal Discharge & 296 & 98.67 \\
\hline Pain lower abdomen & 120 & 40.00 \\
\hline Pruritus vulva & 60 & 20.00 \\
\hline Dyspareunia & 54 & 18.00 \\
\hline Foul smelling & 4 & 1.33 \\
\hline
\end{tabular}

The mean age of the study group was $31.5 \pm 6.085$ yrs. Majority were between 31 to 40 years of age (48.33\%).

Table 2: Distribution of the cases according to per speculum findings (syndromic).

\begin{tabular}{|c|c|c|}
\hline Per speculum & Number & Percentage \\
\hline Normal & 97 & 32.33 \\
\hline Thin watery discharge & 117 & 39.00 \\
\hline Thick curdy white discharge & 79 & 26.33 \\
\hline $\begin{array}{l}\text { Green frothy discharge foul } \\
\text { smelling }\end{array}$ & 7 & 2.33 \\
\hline Total & 300 & 100 \\
\hline
\end{tabular}

RTIs were more common in Rural women than urban (60\% vs $40 \%)$.

Majority (95\%) of them were married. very few were widow or divorcee.

Most of them belonged to lower middle class (43.67\%) followed by upper middle class (22\%) as per Kuppuswamy socioeconomic status classification.
Table 3: Distribution of the cases according to Per vaginal findings (syndromic).

\begin{tabular}{|lll|}
\hline & Number & Percentage \\
\hline $\begin{array}{l}\text { Normal } \\
\text { Ut. bulky, Tenderness in }\end{array}$ & 249 & 83.00 \\
\hline $\begin{array}{l}\text { Ut. N size, Tenderness } \\
\text { in fornix }\end{array}$ & 21 & 7.00 \\
\hline Total & 31 & 10.00 \\
\hline
\end{tabular}

Table 4: Distribution of the cases according to whiff test (Etilogical).

\begin{tabular}{|lll|}
\hline Whiff test & Number & Percentage \\
\hline Negative & 217 & 72.33 \\
\hline Positive & 83 & 27.67 \\
\hline Total & 300 & 100 \\
\hline
\end{tabular}

Most common Chief Complain reported was abnormal vaginal discharge $96.33 \%$ in present study. Lower abdominal pain was present in $40 \%$ of cases whereas itching were present in $20 \%$ cases while $18.67 \%$ were reported with complains of dyspareunia.

Table 5: Distribution of the cases according to wet mount (Etilogical).

\begin{tabular}{|lll|}
\hline Wet mount & Number & Percentage \\
\hline Normal & 147 & 49.00 \\
\hline $\begin{array}{l}\text { Hyphae and Pseduo } \\
\text { Hyphae seen }\end{array}$ & 75 & 25.00 \\
\hline Clue cells seen & 69 & 23.00 \\
\hline Flagellated protozoa seen & 9 & 3.00 \\
\hline Total & 300 & 100 \\
\hline
\end{tabular}

Gram staining was found Normal in 217 (72.33\%) cases, pus cells, gram positive bacteria were seen in $13.67 \%$ cases. Pus cells, gram negative bacteria were seen in $14 \%$ cases.

Table 6: Distribution of the cases according to gram staining (Etiological).

\begin{tabular}{|lll|}
\hline Gram staining & Number & Percentage \\
\hline Normal & 217 & 72.33 \\
\hline $\begin{array}{l}\text { Pus cells, gram positive } \\
\text { bacteria seen }\end{array}$ & 41 & 13.67 \\
\hline $\begin{array}{l}\text { Pus cells, gram negative } \\
\text { bacteria seen }\end{array}$ & 42 & 14.00 \\
\hline Total & 300 & 100 \\
\hline
\end{tabular}

Out of 300 cases In ELISA test, HBs Ag was positive in $9(3 \%)$ cases, VDRL positive cases were in $1.67 \%$ and HIV positive were $0.67 \%$ cases.

Out of 300 cases in $186(62 \%)$ cases pap smears were reported normal, $32.33 \%$ cases were inflammatory, $2 \%$ bacterial vaginosis, $2.33 \%$ candidiasis, $0.67 \%$ 
trichomoniasis and $0.67 \%$ were low grade squamous epithelial lesion (LSIL).

Table 7: Distribution of the cases according to vaginal swab culture (Etiological).

\begin{tabular}{|lll|}
\hline Vaginal swab culture & $\begin{array}{l}\text { Number } \\
(\mathbf{N}=300)\end{array}$ & Percentage \\
\hline Normal & 210 & 70.00 \\
\hline candida spp. & 81 & 27.00 \\
\hline Trichomoniasis & 9 & 3.00 \\
\hline Total & 300 & 100 \\
\hline
\end{tabular}

Per vaginal findings were normal in $83 \%$ cases. Tenderness were present in $17 \%$.

Table 8: Distribution of the cases according to Elisa Test.

\begin{tabular}{|lll|}
\hline ELISA Test & $\begin{array}{l}\text { Number } \\
(\mathrm{N}=300)\end{array}$ & Percentage \\
\hline HbsAg & 9 & 3.00 \\
\hline VDRL & 5 & 1.67 \\
\hline HIV & 2 & 0.67 \\
\hline
\end{tabular}

On the basis of etiological diagnosis out of 300 cases 147 $(49 \%)$ cases were normal, Bacterial vaginosis was diagnosed in $21 \%$ cases, candidiasis was observed in $20.33 \%, 6.67 \%$ cases had mixed infection and $3 \%$ were of Trichomonas.

Table 9: Distribution of the cases according to Pap Smear.

\begin{tabular}{|lll|}
\hline Pap smear & Number & Percentage \\
\hline Normal & 186 & 62.00 \\
\hline Inflammatory & 97 & 32.33 \\
\hline $\begin{array}{l}\text { Inflammatory, bacterial } \\
\text { vaginosis }\end{array}$ & 6 & 2.00 \\
\hline Inflammatory, candidiasis & 7 & 2.33 \\
\hline $\begin{array}{l}\text { Inflammatory, } \\
\text { trichomoniasis }\end{array}$ & 2 & 0.67 \\
\hline $\begin{array}{l}\text { low grade squamous } \\
\text { epithelial lesion (LSIL) }\end{array}$ & 2 & 0.67 \\
\hline Total & 300 & 100 \\
\hline
\end{tabular}

On the basis of syndromic diagnosis Out of 300 cases most commonly diagnosed syndromes was vaginal discharge syndrome $(54 \%)$ followed by lower abdominal pain syndrome $(17.33 \%)$. No cases of genital ulcers and genital warts were reported.
In the present study, $162(54 \%)$ of women positive for Vaginal discharge syndrome. However Syndromic discharge (VDS) correlated poorly with laboratory evidence of RTIs, with sensitivity of $64.71 \%$ and specificity of $57.14 \%$ PPV $61.11 \%$ and NPV was $60.87 \%$ with accuracy $61 \%$.

Table 10: Distribution of the cases according to syndromic diagnosis.

\begin{tabular}{|lll|}
\hline Syndromic & Number & Percentage \\
\hline Normal & 86 & 28.67 \\
\hline $\begin{array}{l}\text { Vaginal discharge } \\
\text { syndrome (VDS) }\end{array}$ & 162 & 54.00 \\
\hline $\begin{array}{l}\text { Lower Pain Abdomen } \\
\text { Syndrome }\end{array}$ & 52 & 17.33 \\
\hline Genital warts & 0 & 0.00 \\
\hline Genital Ulcers & 0 & 0.00 \\
\hline Total & 300 & 100 \\
\hline
\end{tabular}

Table 11: Distribution of the cases according to final (etiological) diagnosis.

\begin{tabular}{|lll|}
\hline Etilogical diagnosis & Number & Percentage \\
\hline Normal & 147 & 49.00 \\
\hline Bacterial & 63 & 21.00 \\
\hline Candidiasis & 61 & 20.33 \\
\hline Mixed infection & 20 & 6.67 \\
\hline Trichomonas & 9 & 3.00 \\
\hline Total & 300 & 100 \\
\hline
\end{tabular}

Table 12: Association of syndromic and etiological diagnosis.

\begin{tabular}{|llll|}
\hline $\begin{array}{l}\text { Syndromic } \\
\text { and } \\
\text { etiological } \\
\text { diagnosis }\end{array}$ & $\begin{array}{l}\text { Normal } \\
\text { No. }(\%)\end{array}$ & $\begin{array}{l}\text { lower pain } \\
\text { abdomen } \\
\text { syndrome No. } \\
(\%)\end{array}$ & $\begin{array}{l}\text { VDS } \\
\text { No. } \\
(\%)\end{array}$ \\
\hline Normal & 53 & 31 & 63 \\
$(61.63 \%)$ & $(59.62 \%)$ & $(38.89 \%)$ \\
\hline Bacterial & 21 & 15 & 27 \\
vaginosis & $(24.42 \%)$ & $(28.85 \%)$ & $(16.67 \%)$ \\
\hline candidiasis & 7 & 1 & 53 \\
\hline Mixed & $(8.14 \%)$ & $(1.92 \%)$ & $(32.72 \%)$ \\
infection & 5 & 3 & 12 \\
\hline Trichomonas & 0 & 2 & $(7.41 \%)$ \\
\hline Total & $(0 \%)$ & $(3.85 \%)$ & 7 \\
\hline & $(100 \%)$ & $(4.32 \%)$ \\
\hline
\end{tabular}

Table 13: Diagnostic statistics of Vaginal discharge syndrome (VDS) considering the etiological diagnosis.

\begin{tabular}{|cllll|} 
& VDS & Present No. $(\%)$ & Absent No. (\%) & Total No. (\%) \\
\cline { 2 - 5 } Syndromic Diagnosis & Present & $99(64.71 \%)($ Sensitivity) & $63(42.86 \%)$ & $162(54 \%)$ \\
& Absent & $54(35.29 \%)$ & $84(57.14 \%)$ Specificity & $138(46 \%)$ \\
\hline & Total & $153(100 \%)$ & $147(100 \%)$ & $300(100 \%)$ \\
\hline
\end{tabular}


In the present study, $52(17.33 \%)$ of women positive for Lower Pain Abdomen Syndrome. However, correlated poorly with laboratory evidence of RTIs, with sensitivity of $21.74 \%$ and specificity of $84.62 \%$ PPV $38.46 \%$ and NPV was $70.97 \%$ with accuracy $65.33 \%$.

Table 14: Diagnostic statistics of Syndromic (Lower Pain Abdomen Syndrome) considering the etiological diagnosis.

\begin{tabular}{|lllll|} 
& Lower Pain & Present & Absent & Total \\
& Abdomen Syndrome & No $(\%)$ & No $(\%)$ & No $(\%)$ \\
\hline $\begin{array}{l}\text { Syndromic } \\
\text { diagnosis }\end{array}$ & Present & $20(21.74 \%)$ (Sensitivity) & $32(15.38 \%)$ & $52(17.33 \%)$ \\
\cline { 2 - 5 } & Absent & $72(78.26 \%)$ & $176(84.62 \%)($ specificity) & $248(82.67 \%)$ \\
\hline
\end{tabular}

Table 15: Comparative statistics of syndromes.

\begin{tabular}{|lll|} 
& $\begin{array}{l}\text { Vaginal discharge } \\
\text { syndrome (VDS) \% }\end{array}$ & $\begin{array}{l}\text { Lower Pain } \\
\text { Abdomen } \\
\text { Syndrome \% }\end{array}$ \\
\hline Sensitivity & $64.71 \%$ & $21.74 \%$ \\
\hline Specificity & $57.14 \%$ & $84.62 \%$ \\
\hline PPV & $61.11 \%$ & $38.46 \%$ \\
\hline NPV & $60.87 \%$ & $70.97 \%$ \\
\hline Accuracy & $61 \%$ & $65.33 \%$ \\
\hline
\end{tabular}

\section{DISCUSSION}

Reproductive tract infections are most common gynecological complaint among women in reproductive age group.

The study was conducted on 300 women of reproductive age group (20-45 yr) attending the gynecology OPD during December 2015 to June 2017 at Mahatma Gandhi Medical College and Hospital who fulfilled the eligibility criteria. After taking Detailed menstrual, obstetric and sexual history of the patients and General, physical and local examination and investigation were done. Then considering Etiological Diagnosis as gold standard method comparison of sensitivity and specificity of syndromes were calculated.

\section{Distribution of age group}

The mean age of the study group was $31.52 \pm 6.085$ (20 to 45) yrs out of which 145 patients $(48.33 \%)$ were in the age group of $31-40 y r s$, While $43 \%$ in age group of 20 $30 \mathrm{yr}$ and $8.67 \%$ in age group of 41-50 yrs. The same age group was studied by Aggarwal P et al. In his study he showed that majority of patients were between the age group of 31 to 40 years $(36.3 \%) .{ }^{12}$ Distribution of patient according to Sociodemographic status. In present study most of the patients $180(60 \%)$ belong to rural area and while $120(40 \%)$ patients were from urban area. The present study showed that the rural women suffer more than urban $(60 \%$ vs $40 \%)$ from reproductive tract infection.
Ray $\mathrm{K}$ et al showed in their study that reproductive tract infections were more common in rural women than urban population. ${ }^{12}$

\section{Distribution of patient according to marital status}

In present study Out of 300 patients $285(95 \%)$ patients were married, while $4 \%$ were divorcee, while only $1 \%$ widow had the complaints of reproductive tract infection.

Bohra et al carried out similar study in Nepal mentioned that symptoms related to RTIs was common in young married women. ${ }^{13}$

\section{Distribution of patients according to education}

In present study analysis out of 300 cases $31.67 \%$ were educated till secondary, $20 \%$ were having primary education, $15.33 \%$ were Illiterate were and higher education holder were $17.67 \%$.

Ghebremichael $M$ et al showed in their study that majority of study participants had pre-secondary education $(77 \%){ }^{14}$

\section{Distribution of patients according to socio economic status}

In present study as per kuppuswamy classification of socio economic status maximum no. of patients $131(43.67 \%)$ were lower middle class, while $22 \%$ patients were upper middle class, $13 \%$ patients were lower class and $14.67 \%$ were upper class and $6.67 \%$ patients were upper lower class. Bote MM et al in their study that More than half of women were from higher socioeconomic status. ${ }^{15}$

\section{Distribution according to religion}

$274(91.33 \%)$ patients were Hindu, while 8\% were muslim and only $0.67 \%$ were Sikh. Majority of my patients are Hindu because nearby area is Hindu 
dominated. Bote MM et al in their study $76.4 \%$ were muslim, $20.2 \%$ were Hindu and $3.4 \%$ were others. ${ }^{15}$

\section{Parity}

In present study distribution according to parity of patient revealed that Maximum no. of patients 99 (33\%) were para 2 and $68(22.67 \%)$ patients were primipara, while $14 \%$ patients had no children (nulliparous) and $30.33 \%$ patients were multiparous women (>P3).

Romoren et al in their study showed maximum no. of patient $243(35 \%)$ were primiparous. ${ }^{16}$

\section{Distribution of patient according chief complain (symptoms)}

In present study, out of 300 patients 296 (98.67\%) presented with vaginal discharge. while $40 \%$ patients had pain in lower abdomen, $20 \%$ patient with pruritus vulva, $18 \%$ patient with dyspareunia and $1.33 \%$ patients presented with foul smelling vaginal discharge.

Hawkes et al in their study $94 \%$ women reported with abnormal vaginal discharge, $40 \%$ reported with lower abdominal pain, $55 \%$ were having genital itching and genital ulceration was present in $1 \%$ of cases. ${ }^{17}$

\section{Distribution of patient according Per Speculum examination}

In present study analysis of patients according to findings of per speculum examination out of 300 patients 97 $(32.33 \%)$ had normal vaginal discharge while $117(39 \%)$ presented with excessive homogenous thin watery discharge, 79 (26.33\%) patient had thick curdy white discharge. $7(2.33 \%)$ patient had green frothy discharge with foul smell. Shethwala $\mathrm{N}$ et al showed in their study that most of patients presented with Homogenous white discharge $43(28.7 \%)$ cases, 42(28\%) presented with curdy white discharge. ${ }^{18}$

\section{Per vaginal examination}

In present study analysis of patients according per vaginal examination out of 300 cases 249 (83\%) were normal, $10.00 \%$ cases presented with Normal size uterus and tenderness in fornix and $7 \%$ cases presented with bulky uterus and tenderness in fornix. Fornicial Tenderness was present in cases $17 \%$. Ray $\mathrm{K}$ et al in their study lower abdominal tenderness was observed in $13.5 \%$ of women. ${ }^{11}$

\section{Whiff test finding}

Out of 300 cases whiff test were positive in $83(27.67 \%$ ) cases and negative in $217(72.33 \%)$ cases. Whiff test confirmation of bacterial vaginosis if fishy smell present then whiff test positive

\section{Wet mount finding}

According to wet mount findings were Normal in 147 (49\%) cases, Hyphae and Pseudo Hyphae seen in $25.00 \%$ cases, Clue cells seen in $23 \%$ cases While Flagellated protozoa seen in $3 \%$ cases.

\section{Swab culture finding}

Out of 300 cases Most of the cases $210(70 \%$ ) were sterile on vaginal swab culture. candida species were present in $27 \%$ cases while Trichomoniasis were present in $3 \%$ cases. Swab culture is Confirmatory diagnosis of candida and trichomonas. Vasantha PL et al in their study whiff test, wet mount and vaginal swab culture showed by laboratory diagnosis which was $52 \% .^{19}$

\section{Gram staining finding}

In present study out of 300 patients gram staining was found Normal in 211 (72.33\%) cases, pus cells, gram positive bacteria were seen in $13.67 \%$ cases. Pus cells, gram negative bacteria were seen in $14 \%$ cases.

Gram staining is confirmatory diagnosis of bacterial vaginosis and diagnosis for gram positive and gram negative bacteria. Bohara et al found in their study that thirteen percent had trichomoniasis and $7 \%$ had gonorrhoea identified in Gram stained smears and cultures. ${ }^{13}$

\section{ELISA test finding}

In present study Out of 300 cases In ELISA test, HbsAg was positive in $9(3 \%)$ cases, VDRL positive cases were in $1.67 \%$ and HIV positive were $0.67 \%$ cases. Aggarwal $\mathrm{P}$ et al only two women were HIV positive ; one showed VDRL reactivity, though the VDRL titre was low (1:4), she was also reactive by TPHA test. ${ }^{20}$

\section{Pap smear finding}

In present study on pap smear finding, out of 300 cases $186(62 \%)$ cases were reported normal, $32.33 \%$ cases were inflammatory, $2 \%$ bacterial vaginosis, $2.33 \%$ candidiasis, $0.67 \%$ trichomoniasis and $0.67 \%$ were low grade squamous epithelial lesion (LSIL). Prabha MLS et alPap smear showed $32.9 \%$ inflammatory changes and $0.25 \%$ lowgrade squamous intraepithelial lesion. ${ }^{21}$

\section{Syndromic diagnosis}

In present study Out of 300 cases most commonly diagnosed syndromes was vaginal discharge syndrome $(54.00 \%)$ followed by lower abdominal pain syndrome $(17.33 \%)$. No cases of genital ulcers and genital warts were reported.

Prabha MLS et al prevalence of reproductive tract infections/sexually transmitted infections by syndromic 
diagnosis was $61.9 \% .^{21}$ The most common syndromes diagnosed is vaginal discharge syndrome $(34 \%)$ followed by lower abdominal pain syndrome $(28 \%)$. No cases of genital ulcers and genital warts were reported.

\section{Etiological finding}

In present study analysis of patients on Etiological diagnosis, out of 300 cases 147 (49\%) cases were normal, Bacterial vaginosis was diagnosed in $21 \%$ cases, candidiasis was observed in $20.33 \%, 6.67 \%$ cases had mixed infection and $3 \%$ were of trichomonas. Patnaik et al The most commonly infections identified by laboratory diagnosis was bacterial vaginosis $(14.3 \%){ }^{22}$

\section{Sensitivity and specificity of vaginal discharge syndrome}

In present study for the sensitivity analysis to compare the different diagnostic methods for RTI/STI etiological diagnosis was considered as gold standard method. In the present study, out of total 300 patients 162 (54\%) of women were positive for VDS. However Vaginal discharge syndrome(VDS) correlated poorly with laboratory evidence of RTIs, with sensitivity of $64.71 \%$ and specificity of $57.14 \%$ PPV $61.11 \%$ and NPV was $60.87 \%$ with accuracy $61 \%$. Prabha et al in this study vaginal discharge syndrome sensitivity was $58.95 \%$ and specificity was $55.13 \%$, PPV was $28.57 \%$ and NPV was $81.52 \% .^{12}$

\section{Sensitivity and specificity of lower abdominal pain syndrome}

In the present study, $52(17.33 \%)$ of women positive for Lower Pain Abdomen Syndrome. However, correlated poorly with laboratory evidence of RTIs, with sensitivity of $21.74 \%$ and specificity of $84.62 \%$ PPV $38.46 \%$ and NPV was $70.97 \%$ with accuracy $65.33 \%$.

Prabha et al showed lower abdominal pain syndrome sensitivity is very low $(14.49 \%)$ and high specificity $76.63 \%$, PPV is $11.24 \%$ and NPV is $81.44 \% .^{12}$

Funding: No funding sources Conflict of interest: None declared

Ethical approval: The study was approved by the Institutional Ethics Committee

\section{REFERENCES}

1. Rabiu KA, Adewunmi AA, Akinlusi FM, Akinola OI. Female reproductive tract infections: understandings and care seeking behaviour among women of reproductive age in Lagos, Nigeria. BMC Women's Health. 2010 Mar 23;10(1):8.

2. World Health Organization. Prevention and control of sexually transmitted infections: draft global strategy: report by the Secretariat. In Prevention and control of sexually transmitted infections: draft global strategy: report by the Secretariat. 2006.

3. World Health Organization. Reproductive health strategy to accelerate progress towards the attainment of international development goals and targets, Geneva. 2004:14-19.

4. Wasserheit JN. The significance and scope of reproductive tract infections among Third World women. Int J Gynecol Obstet. 1989 Jan 1;30:145-68.

5. National Research Council. Reproductive health in developing countries: expanding dimensions, building solutions. National Academies Press; 1997 Aug 2.

6. Tankhiwale SS, Chavan SP. Comparative study of syndromic and etiological diagnosis of sexually transmitted infection except human immunodeficiency virus in sexually transmitted infection and reproductive tract infection clinic attendees in central India. Int J Med Public Health. 2013;3(4).

7. Morton RS, Rashid S. The syphilis enigma: the riddle resolved?. Sex Transmit Infect. 2001 Oct 1;77(5):322-4.

8. Dhawan J, Khandpur S. Emerging trends in viral sexually transmitted infections in India. Indian $\mathbf{J}$ Dermatol Venereol Leprol. 2009 Nov;75(6):561.

9. World Health Organization. Prevalence and incidence of selected sexually transmitted infections, Chlamydia trachomatis, Neisseria gonorrhoeae, syphilis and Trichomonas vaginalis: methods and results used by WHO to generate 2005 estimates.Geneva: world Health organization; 2011.

10. Shrivastava SR, Shrivastava PS, Ramasamy J. Utility of syndromic approach in management of sexually transmitted infections: public health perspective. J Coastal Life Med. 2014;2(1):7-13.

11. Ray K, Muralidhar S, Bala M, Kumari M, Salhan S, Gupta SM, Bhattacharya M. Comparative study of syndromic and etiological diagnosis of reproductive tract infections/sexually transmitted infections in women in Delhi. Int J Infect Dis. 2009 Nov;13(6):e352-9.

12. Aggarwal P, Bhattar S, Sahani SK, Bhalla P. Utility of laboratory diagnosis for confirmation of the syndromic case management in married indian women with vaginal discharge. Int J Health Sci. 2016 Oct;10(4):516.

13. Bohara MS, Joshi AB, Lekhak B, Gurung G. Reproductive tract infections among women attending gynaecology outpatient department. Int J Infect Microbiol. 2012 Oct 9;1(1):29-33.

14. Ghebremichael M. The syndromic versus laboratory diagnosis of sexually transmitted infections in resource-limited settings. ISRN AIDS. 2014 Mar 5;2014.

15. Bote MM, Bedre RC, Solanki HB, Shenoy AG, Suryawanshi SR. Syndromic diagnosis vs. laboratory diagnosis of reproductive tract infections among married women of reproductive age group in urban slum of Mumbai. Community Med. 2015;6(4):513-8. 
16. Romoren M, Velauthapillai M, Rahman M, Sundby J, Klouman E, Hjortdahl P. Trichomoniasis and bacterial vaginosis in pregnancy: inadequately managed with the syndromic approach. Bull World Health Organization. 2007Apr;85(4):297-304.

17. Hawkes S, Morison L, Foster S, Gausia K, Chakraborty J, Weeling R, Mabey D. Reproductivetract infections in women in low-income, lowprevalence situations: assessment of syndromic management in Matlab, Bangladesh. Lancet. 1999 Nov 20;354(9192):1776-81.

18. Shethwala N, Mulla S. Study on reproductive tract infection among the female patients attending the gynecology OPD in a teaching hospitals of GujaratIndia. 2014.

19. Vasantha PL, Leela KS. Comparison of laboratory diagnosis and syndromic approach in the management of symptomatic vaginal discharge. IJSR. 2015;4(6):2073-6.
20. Aggarwal P, Bhattar S, Sahani SK, Bhalla P. Utility of laboratory diagnosis for confirmation of the syndromic case management in married indian women with vaginal discharge. Int J Health Sci. 2016 Oct;10(4):516.

21. Prabha ML, Sasikala G, Bala S. Comparison of syndromic diagnosis of reproductive tract infections with laboratory diagnosis among rural married women in Medak district, Andhra Pradesh. Indian J Sex Transmit Dis. 2012 Jul;33(2):112.

22. Patnaik L, Sahu T, Sahani NC. Syndromic diagnosis of RTI/STI among women of reproductive age group. Indian J Community Med. 2008;4(1).

Cite this article as: Saharan S. A study of syndromic and etiological approach for the diagnosis of reproductive tract infections. Int J Reprod Contracept Obstet Gynecol 2018;7:2147-54. 